\title{
QUANDO O ASSUNTO É SOBRE RELIGIÕES DE MATRIZ AFRICANA: LEI 10.6392003
}

\author{
Joanice Santos Conceição*
}

\begin{abstract}
RESUMO
O presente artigo objetiva refletir sobre a aplicação da Lei 10.639/2003, em especial, sobre os aspectos das religiões de matriz africana, tendo em vista que a lei sancionada tornou obrigatório o ensino da história e da cultura africana e afro-brasileira em todas as unidades escolares do País. Entendemos que falar sobre racismo não é tarefa fácil, principalmente no ambiente escolar, que, embora possibilite a construção de conhecimento, cultiva a manutenção de preconceitos e estereótipos em relação a determinados grupos, em especial, negros e indígenas. Esse preconceito é acentuado quando se coloca em relevo as religiões de matriz africana, frente ao crescimento de denominações pentecostais e neopentecostais que têm praticado diversos desrespeitos religiosos por todo o Brasil. Idealmente, a escola brasileira deve fornecer informações históricas relativas às matrizes que deram origem ao País; entretanto, há uma maior valorização do pensamento e culturas eurocêntricas, descuidando-se abundantemente das diversidades culturais, econômicas e tecnológicas do continente africano. O método utilizado é o qualitativo, baseando-se na pesquisa documental e no contato com os professores, revelando assim que a não aplicação da Lei 10.639/2003 resulta de um conjunto de ações e comportamentos, com destaque para o racismo. A partir disso apresento o texto.
\end{abstract}

Palavras-chave: Religião. Currículo. Racismo. Dificuldades. Avanços.

\begin{abstract}
WHEN THE SUBJECT IS THE RELIGIONS ORIGINATING FROM AFRICA: LAW 10639/03:

The present paper aims to reflect on the application of federal law 10639/2003, specifically, on aspects of religions of African origin, regarding that this law, already sanctioned, obliges the teaching of African and Afro-Brazilian history and culture in every school of the country. We understand that it is not very easy to debate over racism, especially inside schools, where, although the construction of knowledge might be made possible, it can also help the maintenance of many prejudices and stereotypes related to some specific groups, particularly, black people and Indians. The racial prejudice is particularly highlighted when focused on the religions of African origin, if we consider the growth of the so-called Pentecostal and neo pentecostal religions that have been disrespectful towards the religions of African origin throughout
\end{abstract}

* Doutora em Ciências Sociais/Antropóloga pela Pontifícia Universidade Católica de São Paulo (PUC/SP). Professora Adjunta da Universidade Federal Fluminense (UFF). Integrante do Grupo de Pesquisas Ritual, Festa e Performance da Universidade Federal de Sergipe (UFS). Participante do Núcleo de Pesquisa Gênero, Raça, Cultura e Sociedade Candaces da Universidade do Estado da Bahia (UNEB). Endereço institucional: Av. João Jasbick, São Jasbick, SNNo, Bairro Aeroporto Santo Antônio de Pádua, Rio de Janeiro-RJ. CEP: 28470-000. joaniceconceicao@gmail.com 
the country. It is vital that the schools within the country should provide historical information regarding the origins of nations that constructed the country, however there is an over valorization of the European culture and thoughts, ignoring to a large the cultural, economical and technological diversity and contribution coming from the African continent. The method used is qualitative, based on documentary research and on contact with the teachers, revealing that the failure to enforce the Law 10639/2003 results from a set o actions and behaviors, especially racism. From this, I present the text.

Keywords: Religion. Curriculum. Racism. Difficulties. Advances.

\section{RESUMEN}

\section{CUANDO EL ASUNTO ES SOBRE RELIGIONES DE MATRIZ ÁFRICA: LEY $10.639 / 2003$}

Este artículo tiene como objetivo reflexionar sobre la aplicación de la Ley 10639/03, en particular sobre los aspectos de las religiones de origen africana, teniendo en cuenta que la ley sancionada hace obligatoria la enseñanza de la Historia de África y Cultura africano-brasileño en todas las escuelas del país. Entendemos que hablar sobre el racismo no es una tarea fácil, principalmente en el ambiente escolar, que a pesar de permitir la construcción de conocimiento, mantiene muchos preconceptos y estereotipos sobre determinados grupos, en particular negros e indígenas. Este prejuicio se acentúa cuando se coloca a la luz religiones de origen africano, contra el crecimiento de las pentecostales y neo-pentecostales que han practicado variados irrespetos religiosos en todo Brasil. Idealmente la escuela brasileña debe proporcionar información histórica sobre las matrices que llevaron a la configuración del país, sin embargo hay un mayor aprecio del pensamiento y culturas euro-céntricas, dejando de lado la abundante diversidad cultural, económica y tecnológica del continente africano. El método utilizado es cualitativo, basado en la investigación documental y el contacto con los maestros, revelando desde un conjunto de acciones y comportamientos que el racismo es la causa principal para la no aplicación de la ley 10.639/2003. A partir de esto presento este texto.

Palabras claves: Religión. Currículo. Racismo. Dificultades. Avances.

\section{Introdução}

"Ninguém nasce odiando outra pessoa pela sua cor de pele, por sua origem ou ainda por sua religião. Para odiar, as pessoas precisam aprender; e se podem aprender a odiar, podem ser ensinadas a amar." (MANDELA, 2013).

As lembranças que tenho da minha infância me transportam para um mundo muito prazeroso: histórias contadas e vividas no seio da família e pessoas próximas; contudo, ao lado dessas vivências em um país como o Brasil, multirracial, cujos princípios estão fortemente arraigados nos padrões eurocêntricos, tornava-se quase impossível não me deparar e envolver em situações de preconceitos e racismo, sendo eu uma criança negra. $\mathrm{O}$ ambiente escolar como parte dessa sociedade não esteve isento dessas situações.

Nos meus primeiros anos escolares, na década de 1970, a partir de uma foto, pude verificar que a discriminação se dava, dentre outras maneiras, na distribuição de alunos e alunas na sala de aula; isto é, alunos brancos, com uniformes mais novos, eram colocados à frente, enquanto os alunos negros e pobres eram colocados nos fundos das classes. Outras formas de racismos e preconceitos eram praticadas 
em sala de aula, tais como a apresentação das cultu$\operatorname{ras}^{1}$ africanas, sobretudo os aspectos religiosos, que eram associados a bruxaria, feitiçaria ou magia negra, em detrimento da hegemonia católica da elite branca. Nunca fui escolhida para ser "Rainha do Milho", ainda que vendesse milhares de bilhetes; também nunca fui anjo nas procissões da cidade e, nas quadrilhas juninas, presenciei por vários anos meninas negras formarem par com outras meninas igualmente negras porque nenhum menino se dispunha a dançar com elas. Essas eram, e talvez ainda sejam, formas explícitas de racismo no ambiente escolar. Com certeza, devem ter existido formas veladas de racismo na minha infância, porque o racismo sempre existiu na sociedade brasileira, fato que talvez justifique a naturalização por parte de algumas pessoas e setores.

Nas escolas onde estudei, todos os alunos, independentemente do credo que professavam, eram obrigados a participar das aulas de religião, ou melhor, das aulas de catolicismo, já que o conteúdo era todo ele voltado para os dogmas católicos. As aulas incutiam em mim e nos outros alunos as ideias de pecado e de culpa. Quase nunca ouvia falar positivamente sobre as religiões praticadas no continente africano, exceto para ser usadas como exemplos pejorativos, ressaltando a satanização de suas concepções religiosas. Para dizer melhor, pouco ou quase nada diziam sobre o continente africano e os escravizados no Brasil, senão para render homenagens à princesa Isabel. As associações feitas eram sempre negativas; associavam e associam o continente africano à AIDS, à fome e à miséria, à selvageria e a outros males. Já os fatores positivos, julgados pela hegemonia branca, eram tratados como não pertencentes ao continente africano, como, por exemplo, a cultura egípcia.

Essa realidade vivida nos anos 1970 não se distancia dos fatos vividos na contemporaneidade. $\mathrm{O}$ negro no século XXI ainda tem uma vida precária, sua cultura vilipendiada, seus corpos ridicularizados. Decerto, um povo que resistiu aos horrores da escravidão não se conformaria com tais tratamentos preconceituosos e discriminatórios, como aponta o trecho a seguir:

\footnotetext{
$1 \mathrm{O}$ termo cultura será tomado aqui a partir do conceito formulado pelo antropólogo Geertz (1989), para o qual a cultura é uma teia de significados tecida pelo homem. Em outras palavras, para ele a cultura é feita por construções simbólicas, significados contidos em um conjunto compartilhado pelos indivíduos.
}

Todo esse processo resultou em um amadurecimento e mudança de rumo do Movimento Negro no terceiro milênio. A partir desse momento, as suas reivindicações passam a focar uma outra intervenção política: a denúncia da postura de neutralidade do Estado frente a desigualdade racial reivindicando do mesmo a adoção de políticas de ação afirmativa e a intervenção no interior do próprio Estado mediante a inserção de ativistas e intelectuais do Movimento Negro nas administrações municipais e estaduais de caráter progressista e no próprio governo federal. No entanto, mesmo quando essa inserção acontece ao ser comparada com o segmento branco da população, acaba por revelar a continuidade da desigualdade. Os negros ainda encontram-se, na sua maioria, representados de forma precária e, por vezes, subalterna, nos escalões do poder. (GOMES, 2009, p. 3).

Segundo Arroyo, Caldart e Molina (2004), os conhecimentos dos mais empobrecidos e discriminados fazem a politização dos currículos escolares, suprindo as lacunas deixadas pela formação da sociedade de um modo geral; assim, é necessário inserir saberes e práticas para que haja uma educação emancipatória; o seu contrário está a contribuir para a existência de grupos marginalizados, inferiorizados e até mesmo desumanizados.

A desumanização caracterizada pela ausência de nomes próprios, de constelação familiar, da associação das ilustrações dos personagens negros a animais, foi corrigida nos textos e sugeridas correções nas ilustrações.

Ser chamado pelo nome próprio ou pelo apelido afetivo familiar é importante para a construção da autoestima e identidade étnico-racial. A distinção do outro pela cor de sua pele, pelo gênero ou direção sexual, desqualifica a pessoa enquanto ser humano e cidadão. As pessoas a quem se confere os atributos de humanidade e cidadania não são nomeadas pela cor de sua pele, pelo seu gênero ou direção sexual, como o branco, o homem, o heterossexual deste país. Pais e professores devem estimular seus filhos e alunos a não aceitarem ser chamados por apelido ou atributo de cor, gênero ou direção sexual, como um princípio formativo de autoestima, autorrespeito e fortalecimento do ego (SILVA, A., 2010, p. 38).

Poderíamos então indagar: O que de fato mudou com o advento da Lei 10.639? As crianças e adolescentes têm aprendido mais sobre a cultura africana? De que forma os professores têm lidado 
com a cultura afro-brasileira e africana em sala de aula? Em que medida o quesito religião tem se tornado o "calcanhar de Aquiles" da lei supramencionada? Estes e outros questionamentos serão alvo de nossa preocupação ao longo dessa escritura.

Tendo em vista que a Lei n. 10.639, de 09 de janeiro de 2003, é muito complexa, por uma questão de delimitação de tema, este artigo irá dedicar atenção aos aspectos da religião ${ }^{2}$ de matriz africana nas instituições de ensino brasileiro.

\section{Da Legislação ao Banco Escolar: Religião de Matriz Africana}

As religiões de matriz africana sempre se firmaram como elo de resistência e luta pela liberdade do povo negro, desde os primeiros dias do cativeiro até os dias atuais; mas nem sempre existiu uma lei para assegurar a sua prática. Ao contrário, há vários relatos que dão conta de proibição, prisão e cerceamento; inicialmente, das práticas do candomblé, e, mais tarde, da umbanda. Foi através de muito sofrimento que a população negra, ao longo do tempo, concretizou as bases que serviriam para a preservação e a continuidade dos valores civilizatórios africanos, dentre os quais a cultura religiosa, que se caracteriza enquanto resistência e lutas.

Com relação ao ensino religioso de matriz africana nas escolas, a história tem mostrado mudanças ocorridas nos últimos séculos e na primeira década do século XXI, especialmente nas Leis de Diretrizes e Bases da Educação (LDB), composta pelas leis n. 4.024, de 20 de dezembro de 1961, n. 5.692, de 11 de agosto de 1971 e n. 9.394 , de 20 de dezembro de 1996, que não diminuíram as atitudes e estereótipos em relação ao negro. Quando a temática é a religiosa de matriz africana, em algumas leis ela sequer é mencionada, como veremos no apanhado histórico que segue.

De diferentes formas, o ensino religioso no Brasil foi regulamentado. $\mathrm{O}$ art. $5^{\circ}$ da Constituição

2 A palavra religião vem do latim re-ligare, isto é, ligar novamente, religar os homens e mulheres com Deus. Pode ser entendida como um conjunto de rituais e códigos morais que derivam das crenças em um Deus superior. Em outras palavras, é sistema de doutrinas, crenças e práticas rituais próprias de um grupo social, estabelecido segundo uma determinada concepção de divindade e da sua relação com o homem; fé (HOUAISS, 2001). do Império de 1824 versa que "A religião católica apostólica romana continuará a ser a religião do Império. Todas as outras religiões serão permitidas com seu culto doméstico ou particular, em casas para isso destinadas, sem forma exterior de templo" (BRASIL, 1824); porém, com a Proclamação da República, em 15 de novembro de 1889 (Decreto n. 1), houve a separação entre Estado e Igreja (leia-se cristianismo), isto é, o Estado não deveria ter o controle sobre o negócio da Igreja (BRASIL, 1889). Com isso, deveria haver mudança na forma de ver as religiões de base africana, já que mesmo após a Lei Áurea havia muitos preconceitos e discriminações em relação às manifestações culturais e crenças religiosas do povo africano e seus descendentes por serem orientados por concepções diferentes das suas.

Por conseguinte, a Constituição de 1891, no art. 72, parágrafo $6^{\circ}$, afirma: “[...] Será leigo o ensino ministrado nos estabelecimentos públicos" (BRASIL, 1891). Em 1931, 40 anos depois, pelo Decreto n. 19.941, de 30 de abril, passou a ser facultativo "[...] nos estabelecimentos de instrução primária, secundária e normal, o ensino da religião (art. $1^{\circ}$ )" (BRASIL, 1931); além disso, a aplicação da matéria religiosa estava condicionada à existência de pelo menos 20 alunos (art. $3^{\circ}$ ). Ainda no decreto acima referido, cabia aos sacerdotes dos cultos oferecidos a escolha dos livros a serem adotados e a definição dos programas da referida disciplina (art. $4^{\circ}$ ), bem como a vigilância e a inspeção da doutrina religiosa e moral dos docentes $\left(\operatorname{art} .5^{\circ}\right)$. Era ainda responsabilidade das autoridades religiosas a indicação dos professores, como pregava o art. $6^{\circ}$. Até mesmo os horários escolares eram determinados pelas autoridades religiosas, rezava o art. $7^{\circ}$ do decreto de 1931 , ressalvando que não poderia haver perda para o aluno quanto às demais disciplinas.

Em contrapartida, havia dentro das instruções para o ensino religioso a orientação para que não houvesse prejuízo no cumprimento do "horário das aulas das demais matérias do curso", dizia o art. $8^{\circ}$. No que diz respeito à suspensão do ensino religioso, isto poderia ser feito pelo Ministro da Educação e Saúde Pública, com apenas um aviso, como salientou o art. 11 do mesmo Decreto (BRASIL, 1931). 
Note-se que no ano de 1931, no Decreto n. 19.941, que tratava acerca do ensino religioso, nenhuma palavra foi escrita sobre a religião de matriz africana; mas continuemos o passeio histórico pela legislação brasileira.

No art. 153 da Constituição de 1934, o ensino religioso tornou-se "de frequência facultativa e ministrado de acordo com os princípios da confissão religiosa do aluno manifestada pelos pais ou responsáveis", fazendo parte do quadro de horário "nas escolas públicas primárias, secundárias, profissionais e normais" (BRASIL, 1934). Mais uma vez, a redação é genérica, não fazendo nenhuma menção às religiões africanas.

Já na Constituição de 1937, o art. 133 legisla que "O ensino religioso poderá ser contemplado como matéria do curso ordinário das escolas primárias, normais e secundárias"; entretanto faz uma ressalva ao observar que este não deve ser de caráter obrigatório para os mestres e professores, tampouco para os alunos (BRASIL, 1937). Em 1946, a Constituição, no art. 168, tornou o ensino religioso uma disciplina nas escolas oficiais; porém, sua matrícula era facultativa, observando as especificidades antes expostas no art. 153 da Constituição de 1934. A novidade apresentada era que a confissão religiosa poderia ser feita pelo aluno, desde que este tivesse condições, ou seja, que fosse capaz (BRASIL, 1946). Como no Brasil, de modo geral, os pais são responsáveis pelos filhos até atingir a maioridade, logo, a religião do aluno será a professada pelos pais ou responsáveis.

Pela LDB de 1961, no art. 97, o ensino religioso seria ministrado sem ônus para os cofres públicos; e acrescenta no $\S 1^{\circ}$ que a formação de classe para o ensino religioso não dependeria de número mínimo de alunos como determinava o Conselho Nacional de Educação (CNE), Câmara de Educação Superior (BRASIL, 1961). Já no Parecer CNE/CP n. 097/99, de 6 de abril de 1999, o $§ 2^{\circ}$, do art. 97, legisla acerca do registro de professores de ensino religioso ao afirmar que este seria realizado pela autoridade religiosa respectiva (BRASIL, 1999). Na Constituição de 1967, o art. 168, IV, afirma que o ensino religioso seria de matrícula facultativa, porém comporia o quadro dos horários normais das escolas oficiais de grau primário e médio (BRASIL, 1967).
Em 1971, a LDB, no art. $7^{\circ}$, no conjunto de obrigatoriedade das disciplinas Educação Moral e Cívica, Educação Física, Educação Artística e Programas de Saúde, acrescenta um dispositivo, o qual faz observar por meio do Decreto-Lei n. 369, de 12 de setembro de 1969, em parágrafo único, as regras relativas ao ensino religioso (BRASIL, 1971). Nos anos 1980, com o processo de redemocratização do ensino, grande parte dos movimentos negros reivindicava o reconhecimento de que existiam populações e ensino igualmente diferenciados no território brasileiro, exigindo do governo uma posição. Existia também uma parcela da sociedade que acreditava no mito da democracia racial; portanto, o contingente negro se deparava com a ideologia do branqueamento e com a naturalização do racismo; as relações assimétricas entre os povos brasileiros transcendiam os espaços físicos; tais como as instituições de ensino, elas perpassavam todos os setores, por isso o movimento negro acreditava também que a educação era o caminho para começar a transformação dessa realidade, oportunizando aos alunos negros e brancos conhecer a religião dos ancestrais africanos. Tais reivindicações garantiram algumas conquistas na Constituição de 1988, especialmente voltadas à educação, como as descritas no trecho a seguir:

Art. 19. É vedada à União, aos Estados e aos municípios:

1 - estabelecer cultos religiosos ou igrejas, subvencioná-los, embaraçar-lhes o funcionamento ou manter com eles ou seus representantes, relações de dependência ou aliança, ressalvada, na forma da lei, a colaboração de interesse público.

\section{$[\ldots]$}

Art. 210. Serão fixados conteúdos mínimos para o ensino fundamental, de maneira a assegurar a formação básica comum e respeito aos valores culturais e artísticos, nacionais e regionais.

$\S 1^{\circ} \mathrm{O}$ ensino religioso, de maneira facultativa, constituirá disciplina dos horários normais das escolas públicas de ensino fundamental. (BRASIL, 1988).

Podemos observar que o artigo 210 da constituição supramencionada salienta a importância de fixar os conteúdos mínimos; porém, mostra-se frágil quando os deixa a cargo dos Estados e mu- 
nicípios. O ensino religioso continua na LDB de 1996, observado no art. 33 (BRASIL, 1996). Até aí nenhuma mudança significativa, pois as escolas, no fim das contas, continuavam ministrando as aulas de religião, como assim popularmente eram conhecidas pelos discentes, como base nas ideologias cristãs; todavia, através da Lei n. 9.475, de 20 de dezembro de 1997, a LDB de 1996 foi reformulada, ganhando o art. 33 da Lei n. 9.394/1996 uma alteração apreciável, como mostra o texto de Fernando Henrique Cardoso, à época, presidente da República (BRASIL, 1997):

[...] Faço saber que o Congresso Nacional decreta e eu sanciono a seguinte Lei:

[...] O art. 33 da Lei ${ }^{\circ} 9.394$, de 20 de dezembro de 1996, passa a vigorar com a seguinte redação:

[...] O ensino religioso, de matrícula facultativa, é parte integrante da formação básica do cidadão e constitui disciplina dos horários normais das escolas públicas de ensino fundamental, assegurado o respeito à diversidade cultural religiosa do Brasil, vedadas quaisquer formas de proselitismo.

$\S 1^{\circ}$ Os sistemas de ensino regulamentarão os procedimentos para a definição dos conteúdos do ensino religioso e estabelecerão as normas para a habilitação e admissão dos professores.

$\S 2^{\circ}$ Os sistemas de ensino ouvirão entidade civil, constituída pelas diferentes denominações religiosas, para a definição dos conteúdos do ensino religioso.

Mais uma vez, a redação foi modificada com a intenção de corrigir distorções e ressalvar a diversidade religiosa, no entanto, sabe-se que na prática educacional a diversidade religiosa é considerada em pequena proporção. $\mathrm{O}$ que prevalece é a orientação religiosa baseada no cristianismo, ficando de fora do quadro outras religiões praticadas no Brasil. Não obstante, o Parecer CNE/CP n. 097/99 alertava para a dificuldade de delimitar as matrizes curriculares nacionais para a formação de professores, bem como os critérios para avaliação da disciplina, passando a responsabilidade para estados e municípios (BRASIL, 1999).

Com a brecha deixada pelo Parecer CNE/CP n. 097/99, o ensino religioso foi regulamentado com o cunho confessional, permitindo muitas vezes o desrespeito religioso, especialmente em relação aos praticantes das religiões de matriz africana, como tem mostrado a mídia, resultando, assim, na ausência de discussão em sala de aula, nos livros e materiais didáticos que circulam na escola e que auxiliam na conformação da pessoa. Soma-se a isso o crescimento de professores evangélicos que, ao invés de informar sobre as religiões existentes no Brasil, acabam por fazer proselitismo na sua prática pedagógica. $\mathrm{O}$ ambiente escolar acaba por contribuir para o fracasso e evasão escolar, já que determinados alunos são vitimizados, inferiorizados, não se reconhecendo enquanto centro do processo ensino-aprendizagem.

A diferença é algo que se produz socialmente, via um sentido simbólico e um sentido histórico, localizado, definido. Um exemplo: índios, negros, alunos de periferia, do campo e de outros espaços, muitas vezes, são apontados como maioria entre aqueles que vivenciam o fracasso escolar. Estudos diversos apontam múltiplas razões para tal e, muitas vezes, apontam para os próprios sujeitos ou para as condições sociais que possuem. Esse caminho não permite entender porque, apesar das repetências, insistem em retornar à escola, desmentindo em parte, que a questão de falta interesse, inadaptação, maus resultados seriam suficientes para afastá-los da escola. Para essa população, a escola é ainda um valor e pensá-la exige ter presente dois lados: um que é o aluno e o professor como sujeitos socioculturais, outro que é a própria escola em sua dupla dimensão - espaços de regras, normas, obrigações, deveres, mas também, de vida, relacionamentos, descobertas, acontecimentos (GUSMÃO, 2011, p. 35).

Esse breve passeio pelas legislações brasileiras mostra que, de maneira geral, existe uma regulamentação do ensino religioso; porém, essas leis deixam brechas para que o desrespeito ocorra, tendo em vista que o termo diversidade, por vezes, é entendido como a obrigação de falar de um segmento religioso sem considerar que o universo escolar é composto por indivíduos diversos, religiosamente falando. Isso mostra que o Estado tem grande parcela de culpa nos conflitos religiosos. A laicidade, a neutralidade e a imparcialidade não estão nas leis criadas para o ensino religioso do país.

[...] A inserção do ensino religioso foi garantida por grande maioria dos votantes, bem como o reconhecimento de estabelecimentos particulares e o 
reconhecimento explícito do papel da família como educadora. Ambos os grupos estão satisfeitos. Afinal, o Estado permitiu o conflito, em certo sentido o estimulou e por fim, o arbitrou na medida em que as disposições de ambos os grupos foram incorporadas à Constituição. (CURY, 1988, p. 122-123).

Em termos de direito, de liberdade de escolha e da prática pedagógica, essa é uma questão problemática, na medida em que o indivíduo não possui um leque de possibilidades que lhe permita conhecer de forma ampla as religiões praticadas no Brasil. Neste sentido, o ensino religioso oferecido não contempla a diversidade religiosa do país.

\section{Religião e Racismos}

De certo modo, as políticas públicas de promoção da igualdade racial, conhecidas como ações afirmativas, implementadas nos últimos anos, denunciam as diversas formas de discriminações e racismo silenciosos e estruturantes da sociedade brasileira; portanto, a Lei 10.639/2003 faz parte do conjunto de ações que visam corrigir as desigualdades entre os brasileiros, especialmente no ambiente escolar (BRASIL, 2003). Dentre outros critérios, essa lei ressalta o estudo da história da África e dos africanos, de modo geral, incluindo a história das religiões de matriz africana presentes no Brasil. Para melhor compreender como os aspectos religiosos tornaram-se alvo de racismo, é necessário voltar ao passado para iluminar a realidade atual; é preciso identificar a origem do ódio e ojeriza que cercam as religiões dos orixás.

Antes de os povos africanos serem capturados e escravizados nas terras brasileiras, eles praticavam sua religião a partir dos cultos ligados a suas famílias. Assim, havia regiões que praticavam o culto a Oxum e a sua representação era associada ao Rio Oxum; outra região cultuava Ogum e sua representação estava no ferro; a região que cultuava Yansã fazia reverência aos ventos e às tempestades. Esses três exemplos servem para ilustrar, ainda que de maneira genérica, a associação das religiões de matriz africana com os elementos da natureza e não uma profusão de satanizações disseminadas pelo eurocentrismo que permeia a grande parte do imaginário social. As práticas e manifestações culturais africanas, em grande medida, foram e são mal compreendidas, tirando-lhes até mesmo a sua humanidade; por vezes, seus indivíduos foram tratados como coisas, peça de menor valor comercial.

O Estado e suas políticas têm regulamentado o ensino religioso, mas tais normatizações vêm gerando tensões, tendo em vista que ao longo da história, determinados grupos têm sido privilegiados pela maneira como as leis e os materiais didáticos abordam a temática.

No livro didático a humanidade e a cidadania, na maioria das vezes, são representadas pelo homem branco e de classe média. A mulher, o negros, os povos indígenas, entre outros, são descritos pela cor da pele ou pelo gênero, para registrar sua existência (SILVA, A., 2005, p. 21).

Esta citação fornece informações acerca das matrizes que forjaram a sociedade brasileira, ao passo que ressalta aquelas colocadas à margem do processo de construção da nação. Mulher, negros e indígenas são tratados como seres inferiorizados, sobretudo sem humanidade e sem qualquer direito, permitindo que uma parcela dos professores responsáveis pelo ensino religioso transforme essa disciplina em espaço para evangelizar, para proselitismo, para moldar mentes. Isto fortalece o desrespeito religioso e os ataques às religiões de matriz africana, na medida em que aluno e aluna negros não se reconhecem na educação formal brasileira. A educação dever ser a forma pela qual o ser humano produz a si mesmo, com as ideias, os valores, os símbolos, os hábitos, as atitudes e as habilidades que o torna distinto de outros seres (BARROS et al., 2011).

Os mais de 10 anos da promulgação da Lei $10.639 / 2003$ têm mostrado alguns avanços, tais como maior visibilidade para os temas relativos à cultura africana e afro-brasileira no ambiente escolar, maior disponibilidade de material didático, cursos de formação de professores para educação étnico-racial, maior participação dos alunos nas atividades propostas; entretanto, tanto conversas informais quanto os dados disponíveis relativos à implementação da lei vêm mostrando que ao lado dos avanços há também retrocessos, há resistência, já que alguns temas dentro da lei despertaram muitos preconceitos, em especial a religião, que em muitas escolas não faz parte dos conteúdos porque 
é considerada "religião de satanás", assuntos de bruxaria. Esses fatos são agravados a cada dia, pois muitas crianças praticantes de candomblé e umbandas são alvo de preconceito, desrespeito religioso e até mesmo violência.

Em 2010, a Organização das Nações Unidas para a Educação, a Ciência e a Cultura (Unesco), através da Relatoria do Direito Humano à Educação, revelou vários casos de bullying ${ }^{3}$ devido à intolerância religiosa contra as religiões de matriz africana na escola. A palavra bullying surgiu da palavra bully, cuja origem é inglesa, significando "valentão", já o conceito de bullying nas escolas diz respeito a uma ação negativa, individual ou coletiva, que exponha o outro. A ação é intencional e constante e visa causar ou tentar provocar danos morais, sofrimento e mal-estar a uma pessoa. No caso das religiões não é bullying; é, sim, racismo, preconceito e inferiorização (CARVALHOSA, 2007).

As manifestações de desrespeito religioso crescem até mesmo entre os professores, pois estes se esquecem que seu papel é informar sobre as religiões praticadas no Brasil; e as religiões de matriz africana fazem parte deste conjunto, por isso é importante que os professores conheçam, pelo menos, os símbolos mais significativos das principais religiões brasileiras. Cada religião tem seus símbolos que a representa e utilizam estes significados para expressar-se, porém, o uso de tais símbolos, como, por exemplo, fios de conta, pano na cabeça, são entendidos como afrontas; assim relatam alunos que foram proibidos de entrar no colégio portando seus fios de conta. Isso mostra que os alunos e as alunas, além de não terem os conteúdos relativos à sua religião, têm seus corpos violentados, têm sua liberdade cerceada, levando à exclusão de educandos praticantes das religiões de matriz africana. $O$ processo de uma sociedade verdadeiramente democrática tem que levar em conta a diversidade racial, de classe e de gênero; todavia, o mito da democracia racial no Brasil não faz parte das preocupações das camadas dominantes e conservadoras do país. Não haverá integração nacional

\footnotetext{
3 Segundo Carvalhosa (2007), o conceito de bullying escolar está associado a uma ação negativa, individual ou coletiva que exponha o outro. Essa ação negativa é entendida como intencional e constante e que cause, ou tente causar, danos morais, sofrimento e mal-estar a uma pessoa. $\mathrm{O}$ bullying pode ser físico ou moral, causando prejuízo à pessoa ofendida.
}

enquanto houver grupos racialmente subordinados e politicamente excluídos. O mito da democracia racial investe na ideia de que há harmonia racial e, se há harmonia, não se tem motivo para combater o racismo, portanto a Lei 10.639/2003 não faz qualquer sentido. Além disso, a ideologia cria uma ideia romântica sobre os grupos éticos existentes no Brasil, cujo objetivo é dissipar as tensões e controlar os conflitos que possam surgir (HASENBALG, 1979); mas com a força dos movimentos sociais negros a lei foi promulgada, afirmando de algum modo que o racismo é estruturante na sociedade brasileira.

A lei determina que o conteúdo programático contemple o estudo da história da África e dos africanos e dos afro-brasileiros e suas culturas, reconhecendo sua importância para a construção da sociedade brasileira. A lei ainda especifica que os conteúdos do currículo escolar devem ser implementados, especialmente nas áreas de Educação Artística, Literatura e História brasileira. Ademais, deve possibilitar debates relacionados à diversidade cultural brasileira a fim de desconstruir preconceitos e ampliar as perspectivas, uma vez que a prioridade sempre foi a cultura eurocêntrica.

Um seminário para avaliar os 10 anos da Lei 10639/2003 foi realizado pelo programa de Antropologia da Universidade de São Paulo (USP), em maio de 2013, cuja mesa era composta por Nilma Lino Gomes, Marina de Mello e Souza, Denise de Barros e Petronilha Gonçalves. Para esta última, em artigo publicado em 2007, embora se tenha avançado em muitas questões, "a escola ainda padece das influências históricas desde seu surgimento, no âmbito da lógica colonizadora do século 16 " (SILVA, P., 2007). Isso porque os alunos receberam uma educação massificada em relação aos padrões brancos, de modo a aceitarem o lugar menor e inferiorizante designado pelos padrões hegemônicos, isto é, pelo padrão eurocêntrico (SILVA, P., 2007).

Outra pesquisa intitulada "Racismo e Educação: a Lei n. 10.639/2003 na rede pública do estado de São Paulo", realizada pelo Núcleo de Pesquisa de Relações Raciais, Memória, Identidade e Imaginário, da Pontifícia Universidade Católica de São Paulo (PUC/SP), entre 2013 e 2014, apontou que, na cidade de São Paulo, um dos motivos para a não aplicação da Lei 10.639/2003 nas escolas da capital paulista se deve ao racismo. Os dados mos- 
tram ainda que a religião é o quesito mais difícil de ser implementado, tendo em vista que desde os primórdios a religião de matriz africana sempre ter sido satanizada e isso é reforçado por meio dos livros e conteúdos colocados à disposição dos educandos (ARAÚJO; BERNARDO, 2014). Não obstante toda negatividade que recai sobre as concepções religiosas ligadas aos africanos, os livros didáticos não cumprem com as determinações do Plano Nacional do Livro Didático (PNLD):

[...] no PNLD definem que, quanto à construção de uma sociedade democrática, os livros didáticos deverão promover positivamente a imagem de afrodescendentes e, também, a cultura afro-brasileira, dando visibilidade aos seus valores, tradições, organizações e saberes sociocientíficos. [...] os livros destinados a professores(as) e alunos(as) devem abordar a temática das relações Etnicorraciais, do preconceito, da discriminação racial e violências correlatas, visando à construção de uma sociedade anti-racista, justa e igualitária [...] (BRASIL, 2004, p. 24)..

É necessário, portanto, maior atenção não apenas nos conteúdos veiculados nos livros didáticos, mas aliar a esta necessidade a formação do professor que, por vezes, deve manter o propósito maior da sua informação, que é ensinar, permitindo ao aluno formular suas ideias livremente. Para tanto, os conteúdos sobre a religião devem ser panorâmicos e globais, focando na cultura dos povos que deram origem ao Brasil e não apenas na de um grupo, articulando a formação de professores, produção de material didático e ações educacionais.

$\mathrm{O}$ desafio que se coloca hoje é saber quais as concepções, os conteúdos e as metodologias que podem promover a equidade entre os povos a fim de extinguir a discriminação racial que, dentre outros males, promove o preconceito religioso, especialmente em relação às matrizes africanas. Os desafios podem ser ampliados para a criação de livros e materiais didáticos respeitosos, bem como a formação de professores lhes permitam compreender o seu verdadeiro papel enquanto educador. Ademais, um trabalho em parceria com a família pode possibilitar maior respeito à cultura africana e suas manifestações. Haja vista que a religião é um dos aspectos que ajudam na conformação das identidades do indivíduo, por meio dela é possível se promover uma interação reflexiva no processo de criação e ressignificação do mundo. Parafraseando Boaventura Souza Santos (2006), é preciso descolonizar não apenas o olhar, mas, de igual modo, o currículo escolar.

Muitos educadores, especialmente a maioria dos evangélicos, reduzem a Lei 10.639/2003 apenas à questão religiosa, esquecendo-se de que a aplicação da lei diz respeito a um conjunto de temas relativos ao continente africano e à sociedade brasileira, pois o negro africano e brasileiro precisam ser entendidos na sua plenitude; e a religião é apenas uma das dimensões, dentre outras formas para enxergar o mundo.

$\mathrm{O}$ preconceito e o desrespeito relativo às concepções e manifestações da maioria dos negros data desde a chegada de africanos e africanas ao Brasil, perdurando até os dias atuais. Adjetivações pejorativas colaboram para a construção negativa do candomblé, umbanda, culto de Babá Egun, dentre outras denominações. Palavras como feiticeiro, feitiçaria, mandingueiro, candomblezeiro, macumbeiro, bozó resumem as violências sofridas pelos adeptos das matrizes africanas. O espaço da escola também vem sendo palco de desrespeito; não obstante toda forma de silenciamento, há também a violência física. Caputo (2012), em seu livro Educação nos terreiros e como a escola se relaciona com crianças de candomblé, traz o depoimento de criança de candomblé, mostrando a violência sofrida no ambiente escolar de diferentes formas. Tais violências são praticadas por outros alunos, muitas vezes com a conivência dos professores e do corpo diretivo. São inúmeros relatos que atestam o desrespeito: "A diretora pediu para eu não ir à aula com meus fios de conta", diz Jamile. Ariousto diz: "Quando me iniciei, fui para a escola de boné e a professora disse que só ficaria na sala se tirasse o boné. Mesmo eu explicando pra ela o motivo." 4

Casos como os acima mencionados estão espalhados por todo o Brasil, mas, ao lado de toda violência, vem a resistência forjada nos primeiros tempos de escravidão. A despeito de todo esforço para apagar as manifestações africanas, elas persistem, elas não se deixam silenciar, elas estão no corpo e na memória de seus fiéis e alunos e assim

\footnotetext{
4 Os nomes dos alunos acima referidos são fictícios para preservar seu anonimato. Depoimento colhido em abril de 2015, com alunos da escola estadual localizada no bairro da Federação, em Salvador-BA.
} 
fazem educandos negros e não negros aprender sobre o valor positivo oriundo de África.

\section{Dificuldades e Avanços com a Lei 10.6392003}

As dificuldades para a aplicação da Lei $10.639 / 2003$, no que se refere às religiões de matriz africana, nos mais de 10 anos, foram bastante debatidas. Entraves como a falta de material didático para abordagem do tema, professores sem a qualificação adequada para a temática e falta de comprometimento profissional e vontade política são fatores que aparecem como responsáveis pela não aplicação da lei; contudo, é preciso atentar para o fato de que o racismo, muitas vezes, é silencioso e dissimulado. É preciso localizar a origem da dificuldade, tendo em vista que grande parte da sociedade acredita na superioridade do homem branco em detrimento da inferioridade do negro; isso gera não apenas as desigualdades etnicorraciais, mas a exclusão de indivíduos que não compactuam com essas ideias. Alguns professores acreditam que a aplicação da lei resume-se à preparação de grupos de dança, exposição de comidas de origem africana e concurso de beleza negra. A cultura africana é muito mais complexa, passando pelas tecnologias e pelos métodos refinados de agricultura e medicina, portanto o ensino da cultura africana não pode ficar alheio à sistematização do conhecimento. Segundo Gomes (2009), o tratamento da diversidade cultural africana não pode ficar a critério da boa vontade ou da intuição de cada um. O professor deve ter competência político-pedagógica a ser adquirida pela formação contínua. Quero aqui ainda dedicar atenção para alguns elementos que saltam aos olhos quando o assunto é a religião dos orixás.

Em 2006, quando integrei o primeiro grupo de capacitadores no projeto "A Cor da Cultura", da Fundação Roberto Marinho, ao visitar 18 estados, ministrando aula para inclusão da Lei 10.639/2003 nos currículos escolares, percebi que os professores tinham resistência até mesmo para assistir ao vídeo que abordava a religião. Muitos ficavam mudos, outros saíam da sala, mas eu executava a atividade com pouquíssima participação; percebia que, para além do desconhecimento, havia uma espécie de ojeriza em relação às religiões de matriz africana. Ao retornar em cada estado para verificar a implementação, detectei que em dois dos estados revisitados apenas um pequeno grupo de professores havia incluído no seu planejamento os aspectos religiosos. A maioria dos professores era categórica ao afirmar que poderia trabalhar tudo, menos a religião. Ao indagar os motivos, quase todos diziam que não gostavam da religião dos orixás e encerravam a discussão. Além das dificuldades supramencionadas, o Ministério da Educação aponta outras razões por parte dos professores e do corpo diretivo para a não implantação da lei; salienta, dentre outras, o desconhecimento da legislação e sua obrigatoriedade, bem como a falta de investimento público (BRASIL, 2004). A legislação é enfática ao textualizar sobre o objetivo de se trabalhar os aspectos religiosos:

Proporcionar o conhecimento dos elementos básicos que compõe o fenômeno religioso, a partir das experiências religiosas percebidas no contexto do educando; subsidiar o educando na formulação do questionamento existencial, em profundidade, para dar sua resposta devidamente informada; analisar o papel das tradições religiosas na estruturação e manutenção das diferentes culturas e manifestações socioculturais; facilitar a compreensão do significado das afirmações e verdades de fé das tradições religiosas; refletir o sentido da atitude moral como consequência do fenômeno religioso e expressão da consciência e da resposta pessoal e comunitária do ser humano; possibilitar esclarecimentos sobre o direito à diferença na construção de estruturas religiosas que tem na liberdade o seu valor inalienável. (FONAPER..., 2009, p. 47).

O conteúdo dos Parâmetros Curriculares Nacionais do Ensino Religioso (PCNER) é claro ao justificar a necessidade de se trabalhar tal aspecto; porém, a maioria dos professores desconhece o seu verdadeiro papel na condução dos conteúdos religiosos a eles confiados; o papel dos professores é informar sobre a história dos grupos que fundaram o Brasil. Neste sentido, não cabe aos docentes catequizar, fazer proselitismo ou desqualificar a religião de um determinado segmento. Urge uma compreensão da religião como um traço cultural.

Mais de 10 anos se passaram e eu continuo fazendo formação de professores, e as respostas quase sempre são as mesmas para não se traba- 
lhar os aspectos religiosos. Como consequência disso, temos o grande aumento de desrespeito religioso nas escolas, destruição de templos religiosos, impedimento da realização de festas e rituais públicos como, por exemplo, em algumas comunidades do Rio de Janeiro, onde os traficantes impedem a realização de festas públicas nos terreiros e, em outros tantos casos, determinam o fechamento deles. Soma-se a isso o grande número de professores de denominações pentecostais e neopentecostais que se negam a abordar aspectos religiosos africanos. Existem casos em que os professores evangélicos se recusam a trabalhar a lei na sua totalidade.

Embora, ao longo dos anos, a implementação da Lei 10.639/2003 tenha esbarrado em muitas dificuldades, há que se reconhecer alguns avanços, tais como:

a) criação e oferta de curso de formação continuada para as relações etnicorraciais;

b) no caso das religiões de matriz africana, houve a oferta de palestras com especialistas e sacerdotes da temática;

c) maior inserção no currículo de conteúdos relativos à diversidade racial, econômica, social e cultural da sociedade brasileira, enfatizando a matriz africana e afro-brasileira no processo de construção do Brasil;

d) criação e distribuição de materiais didáticos relativos aos aspectos positivos da cultura africana e afro-brasileira;

e) reconhecimento de que o racismo não é um problema que diz respeito apenas ao negro, já que ele é estruturante; portanto, a luta deve ser conjunta;

f) combate à ideologia do mito da democracia racial e do branqueamento;

g) conscientização de que a Lei 10.639/2003 modificou o arts. 26-A, 79-A e 79-B da Lei 9.394/1996 para inserir os conteúdos relativos à população africana e aos afro-brasileiros; e a religião deve ser contemplada;

h) por fim, maior aceitação da temática por parte de alunos, professores e gestores.

Diante do exposto, entendemos que a escola é um espaço que pode, efetivamente, implementar mudanças, não somente do ponto dos aspectos físicos, mas também subjetivos, que implica na mudança de postura, atitudes e comportamentos, de modo a permitir ao aluno o exercício da cidadania. A implementação, ainda que tenha seus limites, vem provocando mudanças significativas nas diretrizes curriculares, na prática docente e na vida dos alunos negros, já que os mesmos sentem-se contemplados, ainda que de maneira tímida, nos conteúdos ministrados em sala de aula. No dizer de Gomes (2009), a Lei 10.639/2003 faz parte de um conjunto de medidas de política públicas adotadas pelo Estado brasileiro e pelo próprio Ministério da Educação e Cultura (MEC) a fim de valorizar a identidade, a memória e a cultura negra. Mais que isso, a efetivação desta lei pode e deve erradicar ou atenuar as práticas discriminatórias no ambiente escolar, face à banalização em relação aos conflitos raciais travados em tais locais.

A violência racial no ambiente escolar auxilia na manutenção de papéis, isto é, oprimido e opressor. Tais práticas muitas vezes são naturalizadas e vulgarizadas por quem deveria mediar e desconstruir os atos racistas. Ao contrário, na maioria dos casos, o silêncio é a única resposta que o aluno encontra. A adoção da lei é uma ação antirracista em favor das vítimas do racismo e de outras formas discriminatórias narradas em muitos capítulos da história brasileira.

\section{Considerações finais}

A aprovação da Lei 10.639/2003 garante a inserção da cultura africana e afro-brasileira nas escolas; ela também assegura, dentre outros aspectos, a transmissão de informações sobre as bases religiosas do continente africano que acabaram por auxiliar no delineamento da identidade brasileira. Além disso, possibilita a crianças e adolescentes negros(as) e não negros(as) desconstruir estereótipos construídos ao longo dos séculos. Ademais, a implementação da lei é uma forma de sanar o déficit deixado pelo sistema educacional no que toca às religiões de matriz africana; reconhece, ainda, as contribuições religiosas como ferramentas importantes na construção e reconstrução da identidade, tendo em vista que muitas vezes as crianças negras, especialmente as praticantes das religiões africanas, têm suas figuras vilipendiadas, introjetando sentimentos de inferioridade, de opressão, de 
racismo; que são violências silenciadas nos livros e em quase todo o sistema educacional. As religiões foram e são fulcrais na escritura da história do negro brasileiro e foi por meio dela que muitos escravizados deram partida para a sua liberdade, deixaram sua marca social, como, por exemplo, Mãe Menininha, Joãozinho da Gomeia, Eduardo de Paula, Mãe Senhora, dentre outros.

Nessa direção, a aplicação da Lei 10.639/2003 não acontecerá enquanto não houver uma mudança na estrutura educacional; e cabe à escola fazer uma revisão de postura dos profissionais envolvidos. Tal revisão deve contemplar alteração curricular desde a educação infantil até os níveis mais elevados do ensino, na medida em que o racismo perpassa todo o sistema social. Decerto, as sutilezas do racismo é um dos aspectos mais difíceis de ser combatido, pois dissimula, tornando menos agressiva a violência sofrida por meninas e meninos negros na escola nossa de cada dia. A subjetividade ou a dissimulação racial, tratadas, muitas vezes, como bullyng, não podem ser negligenciadas na implementação, sobretudo quando no trato das religiões de matrizes africanas. Para Guimarães (2004), o racismo é referido como uma doutrina, quer se queira científica, quer não, que prega a existência de raças humanas com diferentes qualidades e habilidades, de modo que as raças organizem-se hierarquicamente por qualidades morais, psicológicas, físicas e intelectuais.

Conforme almejei ao longo do texto, a realidade da efetivação da Lei 10.639/2003 e a articulação dos aspectos religiosos de matriz africana ainda constituem um grande desafio a ser superado, já que a religião constitui elemento que corrobora com a construção e reconstrução da identidade da pessoa. Não obstante os avanços da legislação, é preciso uma tomada de consciência e mudança de postura face a essa lei, a fim de combater a persistência de atitudes discriminatórias e desrespeitosas para com as religiões de matriz africana. Urge dar visibilidade às heranças ancestrais africanas preservadas a duras penas no Brasil, pois foi a religião responsável por agregar diferentes grupos étnicos negros, agindo em coletivo nas várias insurreições da história. Por fim, foi por meio da religião que negros e negras inscreveram seu nome na história deste país, ressignificando para preservar no corpo e na memória o legado das diferentes civilizações negro-africanas e afro-brasileiras.

\section{REFERÊNCIAS}

ARAÚJO, P.; BERNARDO, T. Entraves e possibilidades para implementação da Lei 10639/2003. São Paulo: PUC/SP, 2014.

ARroyo, M.; CALDART, R.; MOLINA, M. (Org.). Por uma educação do campo. Petrópolis: Vozes, 2004.

BARROS, Z. S. et. al. Educação e relações étnico-raciais. Brasília, DF: Ministério da Educação, Secretária de Educação Continuada, Alfabetização e Diversidade, 2011.

BRASIL. Constituição Politica do Imperio do Brazil, de 25 de março de 1824. Constituição de 1824. Disponível em: <http://www.planalto.gov.br/ccivil_03/Constituicao/Constituicao24.htm>. Acesso em: 10 mar. 2015.

. Constituição da República dos Estados Unidos do Brasil, de 24 de fevereiro de 1891. Constituição de 1891. Disponível em: <http://www.planalto.gov.br/ccivil_03/Constituicao/Constituicao91.htm>. Acesso em: 10 mar. 2015.

Câmara dos Deputados. Decreto no 19.941, de 30 de abril de 1931. Dispõe sobre a instrução religiosa nos cursos primário, secundário e normal. Disponível em: <http://www2.camara.leg.br/legin/fed/decret/1930-1939/ decreto-19941-30-abril-1931-518529-norma-pe.html>. Acesso em: 10 mar. 2015.

Presidência da República. Constituição da República dos Estados Unidos do Brasil, de 16 de julho de 1934. Constituição de 1934. Disponível em: <http://www.planalto.gov.br/ccivil_03/constituicao/constituicao34. htm>. Acesso em: 10 mar. 2015.

Presidência da República. Constituição da República dos Estados Unidos do Brasil, de 10 de novembro de 1937. Constituição de 1937. Disponível em: <http://www.planalto.gov.br/ccivil_03/constituicao/constituicao37. htm>. Acesso em: 10 mar. 2015.

Presidência da República. Constituição da República dos Estados Unidos do Brasil, de 18 de setembro de 1946. Constituição de 1946. Disponível em: <http://www.planalto.gov.br/ccivil_03/constituicao/constituicao46. 
htm>. Acesso em: 10 mar. 2015.

Presidência da República. Constituição da República Federativa do Brasil de 1967. Constituição de 1967. Disponível em: <http://www.planalto.gov.br/ccivil_03/constituicao/constituicao67.htm>. Acesso em: 10 mar. 2015.

Presidência da República. Constituição da República Federativa do Brasil de 1988. Constituição de 1988. Disponível em: <http://www.planalto.gov.br/ccivil_03/constituicao/constituicao.htm>. Acesso em: 10 mar. 2015.

Decreto n. 1, de 15 de novembro de 1889. Proclama provisoriamente e decreta como fórma de governo da Nação Brazileira a Republica Federativa, e estabelece as normas pelas quaes se devem reger os Estados Federaes. Disponível em: $<$ http://legis.senado.gov.br/legislacao/ListaPublicacoes.action?id=91696\&tipoDocumento=DEC \&tipoTexto=PUB $>$. Acesso em: 10 mar. 2015.

Lei n. 4.024, de 20 de dezembro de 1961. Fixa as Diretrizes e Bases da Educação Nacional. Disponível em: <http://www.planalto.gov.br/ccivil_03/LEIS/L4024.htm>. Acesso em: 10 mar. 2015.

Lei n. 5.692, de 11 de agosto de 1971 . Fixa Diretrizes e Bases para o ensino de $1^{\circ}$ e $2^{\circ}$ graus, e dá outras providências. Disponível em: <http://www.planalto.gov.br/ccivil_03/Leis/L5692.htm>. Acesso em: 10 mar. 2015.

Lei n. 9.394, de 20 de dezembro de 1996. Estabelece as diretrizes e bases da educação nacional. Disponível em: <http://www.planalto.gov.br/ccivil_03/Leis/L9394.htm>. Acesso em: 10 mar. 2015.

Lei n. 9.475, de 22 de julho de 1997. Dá nova redação ao art. 33 da Lei n. 9.394, de 20 de dezembro de 1996, que estabelece as diretrizes e bases da educação nacional. Disponível em: <http://www.planalto.gov.br/ccivil_03/Leis/L9475.htm>. Acesso em: 10 mar. 2015.

Lei n. 10.639, de 9 de janeiro de 2003. Altera a Lei n. 9.394, de 20 de dezembro de 1996, que estabelece as diretrizes e bases da educação nacional, para incluir no currículo oficial da Rede de Ensino a obrigatoriedade da temática "História e Cultura Afro-Brasileira", e dá outras providências. Disponível em: <http://www.planalto.gov. br/ccivil_03/leis/2003/L10.639.htm>. Acesso em: 10 mar. 2015.

Ministério da Educação. Conselho Nacional de Educação. Parecer CNE/CP no 003/2004. Diretrizes Curriculares Nacionais para a Educação das Relações Étnico-Raciais e para o Ensino de História e Cultura Afro-Brasileira e Africana. Disponível em: $<$ http://portal.mec.gov.br/cne/arquivos/pdf/003.pdf $>$. Acesso em: 10 mar. 2015.

Ministério da Educação. Conselho Nacional de Educação. Parecer n. CP nº 097/99, de 6 de abril de 1999.

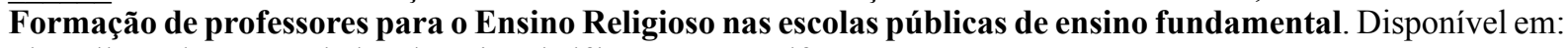
$<$ http://portal.mec.gov.br/cne/arquivos/pdf/pcp097_99.pdf $>$. Acesso em: 10 mar. 2015.

Senado Federal. Plano Nacional de Implementação das Diretrizes Curriculares Nacionais para a Educação das Relações Etnicorraciais e para o Ensino de História e Cultura Afrobrasileira e Africana. Brasília, DF: Senado Federal, 2004.

CARVALHOSA, S. O bullying nas escolas portuguesas. In: SEMINÁRIO DA AAA FPCE-UL 1., 2007, Lisboa. Anais... Lisboa, 2007. Disponível em: < http://aaa.fpce.ul.pt/documentos/seminario_bullying/Resumo_Susana_Carvalhosa.pdf $>$. Acesso em: 10 mar. 2015.

CAPUTO, S. G. Educação em terreiros e como a escola se relaciona com crianças de candomblé. Rio de Janeiro: Pallas, 2012.

CURY, C. Ideologia e educação brasileira: católicos e liberais. São Paulo: Cortez, 1988.

FÓRUM NACIONAL PERMANENTE DO ENSINO RELIGIOSO (FONAPER). Parâmetros curriculares nacionais: ensino religioso. São Paulo: Ave-Maria, 2009.

GEERTZ, C. A interpretação das culturas. Rio de Janeiro: Zahar, 1989.

GOMES, N. L. Limites e possibilidades da implementação da Lei no 10.639/03 no contexto das políticas públicas em educação. In: HERINGER, Rosana; PAULA, Marilene. Caminhos convergentes: estado e sociedade na superação das desigualdades raciais no Brasil. Rio de Janeiro: Henrich Boll Stiftung/Action Aid, 2009. p. 39-74.

GUIMARÃeS, A. S. A. Preconceito e discriminação. São Paulo: Editora 34, 2004.

GUSMÃO, N. M. Antropologia, diversidade e educação: um campo de possibilidades. Ponto-e-Vírgula, São Paulo, n. 10, p. $32-45,2011$. 
HASENBALG, C. A. Discriminação e desigualdades raciais no Brasil. Rio de Janeiro: Graal, 1979.

HOUAISS, A. Religião. Dicionário Houaiss da Língua Portuguesa. Rio de Janeiro: Objetiva, 2001.

MANDELA, Nelson. Frases de Nelson Mandela. Disponível em: <http://culturacomleitura.blogspot.com. br/2013/12/frases-de-nelson-mandela.html>. Acesso em: 10 mar. 2015.

SANTOS, B. S. A gramática do tempo: para uma nova cultura política. São Paulo: Cortez, 2006.

SILVA, A. C. A desconstrução da discriminação no livro didático. In. MUNANGA, K. (Org.). Superando o racismo na escola. Brasília, DF: Ministério da Educação/Secretaria de Educação Continuada, Alfabetização e Diversidade, 2005. p. 21-37.

. Desconstruindo a discriminação do negro no livro didático. Salvador: EDUFBA, 2010.

SILVA, P. B. G. Aprender, ensinar e relações étnico-raciais no Brasil. Educação, Porto Alegre, v. 30, n. 3, p. 489506, dez. 2007.

Recebido em: 14.12 .2015

Aprovado em: 15.03 .2016 